\title{
Publisher Correction: Elastomeric sensor surfaces for high-throughput single-cell force cytometry
}

Ivan Pushkarsky, Peter Tseng, Dylan Black, Bryan France, Lyndon Warfe, Cynthia J. Koziol-White, William F. Jester Jr, Ryan K. Trinh, Jonathan Lin, Philip O. Scumpia, Sherie L. Morrison, Reynold A. Panettieri Jr, Robert Damoiseaux and Dino Di Carlo

Correction to: Nature Biomedical Engineering https://doi.org/10.1038/s41551-018-0193-2, published online 6 February 2018.

In the version of this Article originally published, in Fig. 1a, all cells in the top schematic were missing, and in the bottom-left schematic showing multiple pattern shapes, two cells were missing in the bottom-right corner. This figure has now been updated in all versions of the Article.

Published online: 12 March 2018

https://doi.org/10.1038/s41551-018-0207-0
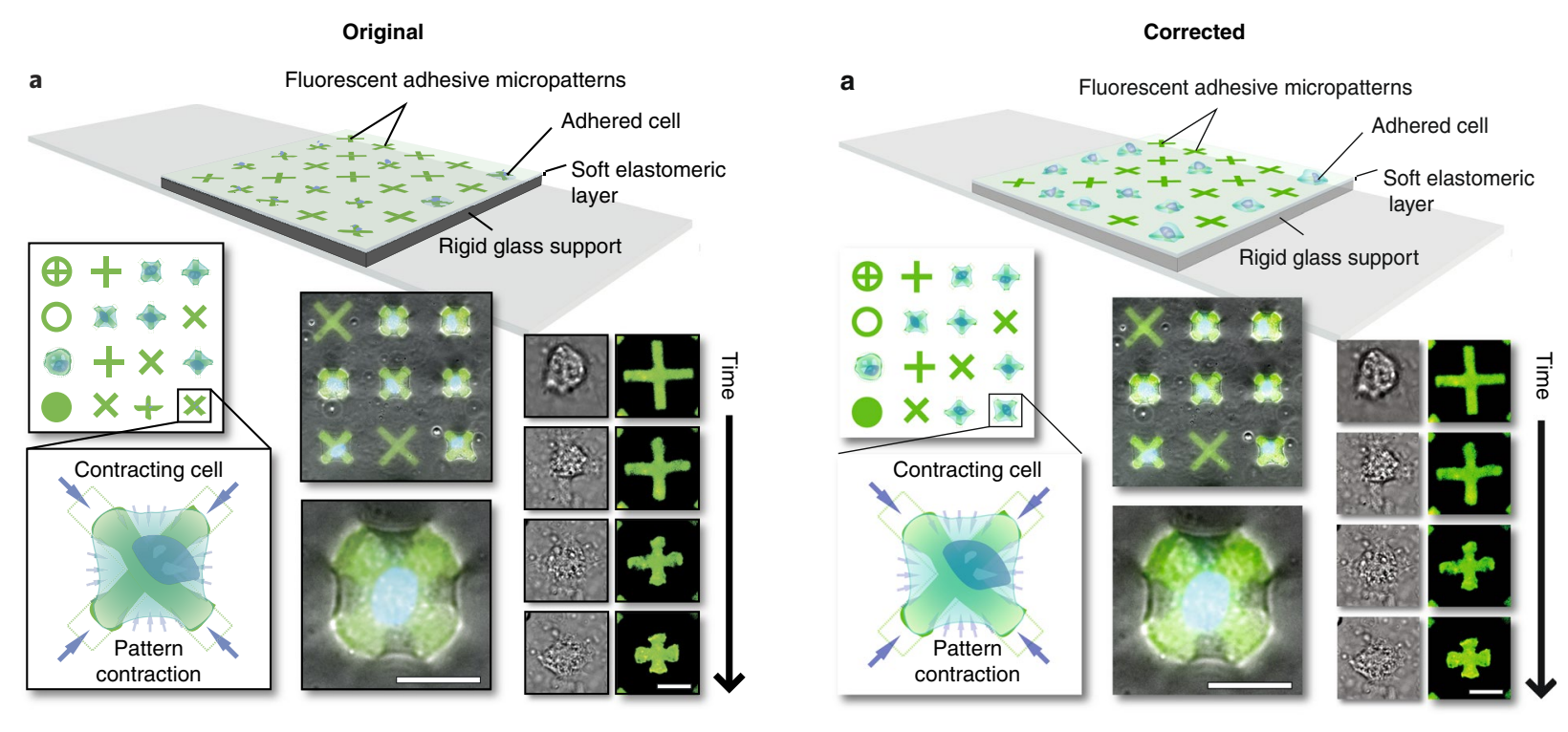

Fig. 1a | Original and corrected. The corrected version includes the cells. 